\title{
Serum concentrations of prolactin, oestrogen and LH during the perioestrous period in prepubertal gilts induced to ovulate and mature gilts
}

\author{
C. A. Pinkert $\dagger$, G. B. Rampacek and R. R. Kraeling* \\ Animal and Dairy Science Department, University of Georgia, Athens, GA 30602, U.S.A. and \\ * Richard B. Russell Agricultural Research Center, Agricultural Research Service, \\ U.S. Department of Agriculture, Athens, GA 30613, U.S.A.
}

\begin{abstract}
Summary. The temporal relationships of serum prolactin, oestrogen and LH concentrations during the perioestrous period were compared in prepubertal gilts induced to ovulate by PMSG and hCG and in mature gilts. In Exp. 1, 2 sustained prolactin surges, beginning 4 days and 1 day before the preovulatory $\mathrm{LH}$ surge, occurred in all mature gilts. A single preovulatory prolactin surge occurred in 3 prepubertal gilts, starting just before the preovulatory LH surge, but 4 prepubertal gilts had neither a prolactin nor an LH surge. A status (prepubertal or mature) versus time interaction $(P<0.01)$ was detected for serum prolactin concentrations. A preovulatory oestrogen surge occurred in all gilts but was of lesser magnitude $(P<0.01)$ and duration $(P<0.05)$ in the prepubertal gilts without prolactin and LH surges compared to mature gilts and of lesser magnitude $(P<0.01)$ compared to prepubertal gilts with prolactin and LH surges. The relative timing of the oestrogen surge in prepubertal gilts corresponded with that of mature gilts when adjusted to the LH surge (if present) but was delayed $(P<0.01)$ in all prepubertal gilts if standardized to the hCG injection. In Exp. 2, mature gilts were examined to determine whether 2 perioestrous prolactin surges were characteristic of all cycling gilts. Of 9 gilts, 8 exhibited an initial prolactin surge $4-5$ days before oestrus and $5 / 9$ gilts exhibited a periovulatory prolactin surge. The presence of 2 perioestrous serum prolactin surges was not a requirement for subsequent pregnancy maintenance. The temporal relationships amongst serum oestrogen, prolactin and $\mathrm{LH}$ concentrations during the perioestrous period were dramatically different in prepubertal gilts induced to ovulate and mature gilts. Such differences may contribute to early pregnancy failure in the prepubertal gilt.
\end{abstract}

Keywords: prolactin; oestrogen; $\mathrm{LH}$; prepubertal; pigs

\section{Introduction}

Induced corpora lutea (CL) of prepubertal gilts appear to be functionally different from naturally formed CL of mature gilts. Hysterectomy after induced ovulation in the prepubertal gilt resulted in CL maintenance, indicating adequate luteotrophic support, yet $C L$ regressed if the gravid uterus was present (Rampacek et al., 1976). Less uterine tissue after partial hysterectomy (Puglisi et al., 1978), or less exogenous prostaglandin F-2 $\alpha$ after complete hysterectomy (Puglisi et al., 1979) was required to cause regression of induced $\mathrm{CL}$ in prepubertal gilts compared to naturally formed $\mathrm{CL}$ of mature gilts. Furthermore, although oestrogen was luteotrophic in non-pregnant mature gilts (Kraeling et al., 1975), it caused luteal regression in prepubertal gilts induced to ovulate (Rampacek

$\uparrow$ Present address: Department of Animal Sciences, 164 Animal Sciences Center, University of Missouri, Columbia, MO 65211, U.S.A. 
\& Kraeling, 1978). Also, human chorionic gonadotrophin (hCG) was luteolytic in prepubertal gilts induced to ovulate but not in mature cycling gilts (Rampacek et al., 1985).

Perhaps the hormonal environment during the perioestrous period influences subsequent luteal function. The temporal relationships amongst serum concentrations of prolactin, luteinizing hormone ( $\mathrm{LH}$ ) and oestrogen in the mature pig have been described. Oestrogen concentrations were basal until pro-oestrus when a 3-4-fold increase occurred (Bevers et al., 1978; Van Landeghem \& Van de Wiel, 1978; Brinkley, 1981; Van de Wiel et al., 1981). A decline in blood oestrogen concentration began before the preovulatory LH surge, yet the preovulatory LH surge occurred within $24 \mathrm{~h}$ after the onset of behavioural oestrus (Henricks et al., 1972; Brinkley, 1981; Van de Wiel et al., 1981; Barb et al., 1982; Guthrie et al., 1982). Two surges in blood prolactin concentrations occurred during the perioestrous period; one surge began near the end of luteal regression and another surge began just before the preovulatory LH surge (Bevers et al., 1978; Dusza \& Krzymowska, 1979; Brinkley, 1981; Van de Wiel et al., 1981). It appears possible that both of these surges may not occur during every oestrous cycle (Dusza \& Krzymowska, 1979; Foxcroft \& Van de Wiel, 1982).

The same temporal relationships amongst oestrogen, prolactin and $\mathrm{LH}$ in mature gilts may not be present in prepubertal gilts induced to ovulate. Plasma oestradiol concentrations were elevated at pro-oestrus in prepubertal gilts induced to ovulate with PMSG and hCG (Paterson \& Martin, 1981) or PMSG alone (Esbenshade et al., 1982) and ovulation rates were similar to those reported for mature gilts (Rampacek et al., 1976; Esbenshade et al., 1982; Paterson, 1982). The serum prolactin surges observed in the mature pig could be important in ovulation and subsequent function of the CL in prepubertal gilts. Therefore, the objective of this study was to compare the temporal relationships of serum prolactin, $\mathrm{LH}$ and oestrogen concentrations during the perioestrous period in prepubertal gilts induced to ovulate and in mature gilts.

\section{Materials and Methods}

Experiment 1. Ten prepubertal crossbred gilts, 120-130 days of age and $48 \pm 1.6 \mathrm{~kg}$ body weight, were placed in individual pens in a total confinement unit. Ovulation was induced by an injection of 1000 i.u. PMSG (i.m.) followed $72 \mathrm{~h}$ later by $500 \mathrm{i} . \mathrm{u}$. hCG (i.m.). Ten mature gilts, $131 \pm 4.8 \mathrm{~kg}$ body weight and from the same population as the prepubertal gilts, were placed in individual pens in the confinement unit and observed for 2 oestrous cycles of 17-21 days to ensure that movement had not altered oestrous cycle length (Kraeling et al., 1982b). All gilts were checked daily for behavioural oestrus with a boar. Five of the mature gilts were ovariectomized by midventral laparotomy 14 days before blood sampling and were used as environmental controls. Beginning 3 days before anticipated oestrus, gilts (intact and ovariectomized) were checked twice daily for oestrus. Intact and ovariectomized mature gilts were given control injections of saline vehicle to correspond to PMSG and hCG treatments in the prepubertal gilts.

All gilts were artificially inseminated with $50 \mathrm{ml}$ fresh pooled boar semen. Prepubertal and ovariectomized gilts were inseminated 24 and $36 \mathrm{~h}$ after the hCG or second saline injection, while mature intact gilts were inseminated 12 and $24 \mathrm{~h}$ after onset of behavioural oestrus. Reproductive tracts of mature and prepubertal gilts were examined 29-30 days after the onset of oestrus or hCG injection for presence of $C L$, corpora albicantia and viable embryos.

Mature intact gilts were non-surgically cannulated by jugular vein puncture on Day -9 (expected onset of oestrus = Day 0 ). The ovariectomized gilts were cannulated at the same time as the mature intact gilts. Prepubertal gilts were cannulated on Day -7 (Day of $\mathrm{hCG}=$ Day 0 ). The non-surgical procedure was as previously reported (Fonda et al., 1981), with the exception that a gauze pad with bacitracin, neomycin and polymixin B ointment was placed over the puncture site before bandaging. Additionally, catheters were flushed with $3.5 \%$ sodium citrate containing $0.05 \%$ ampicillin after each sampling.

Blood samples $(10 \mathrm{ml})$ were collected every $2 \mathrm{~h}$ in all animals beginning at 08:00 $\mathrm{h}$ on the day after cannulation through to Day 5 after oestrus in mature gilts and Day 5 after hCG in prepubertal gilts. Blood samples were stored at $4^{\circ} \mathrm{C}$ for $12-24 \mathrm{~h}$ and serum was harvested and stored at $-30^{\circ} \mathrm{C}$ until assayed. Serum prolactin was measured in all samples. Serum oestrogen was measured in samples obtained at 24 -h intervals while serum LH concentrations were measured in samples obtained at 4-h intervals for 4 days, before and after the anticipated preovulatory LH surge.

Experiment 2. Ten mature crossbred gilts, $131 \pm 3.4 \mathrm{~kg}$ body weight and exhibiting 1 or more oestrous cycles of 19-21 days duration, were moved from outside lots to individual pens in a confinement unit between Day 10 and Day 15 of the oestrous cycle. All gilts were checked once daily for behavioural oestrus with a boar. Gilts were mated at 0 to $24 \mathrm{~h}$ following the onset of oestrus by artificial insemination with $50 \mathrm{ml}$ of fresh pooled boar semen.

Gilts were nonsurgically cannulated via jugular vein puncture between Day 13 and 15 of the oestrous cycle. Ten $\mathrm{ml}$ blood samples were collected at 08:00, 12:00, 16:00 and 20:00 h beginning the day following cannulation through 
12:00 h on Day 2. Blood samples were stored at $4^{\circ} \mathrm{C}$ for 12 to $24 \mathrm{~h}$ and serum was harvested and frozen at $-30^{\circ} \mathrm{C}$ until assayed for prolactin and $\mathrm{LH}$ concentrations.

Radioimmunoassays. Prolactin concentrations were determined by an homologous double-antibody radioimmunoassay (RIA) as previously reported (Kraeling et al., 1982a). Pig prolactin was used for iodinations (LER-2073 or USDA-pPRL-I-1) and standards (LER-2073). Cross-reactions of the first antibody with FSH (NIH-FSH-P-2), LH (LER-778-4) and GH (growth hormone; NIH-GH-P-526B) were less than $1 \%$. The sensitivity of the assay was $0.2 \mathrm{ng}$ prolactin/tube. Intra-assay and interassay coefficients of variation were 8 and $20 \%$ for a high serum pool $(51 \pm 2 \mathrm{ng} / \mathrm{ml}$; mean \pm s.e.m.; $\mathrm{N}=25$ ) and 8 and $18 \%$ for a low serum pool ( $18 \pm 1 \mathrm{ng} / \mathrm{ml} ; \mathrm{N}=24)$, respectively.

Serum LH concentrations were measured by a heterologous double-antibody RIA (Kraeling et al., 1982a). Antiserum was produced in rabbits against bovine LH (NIH-LH-B9). Purified pig LH was used for iodinations (LER-786-3) and standards (LER-778-4). Cross-reactions of the antiserum with other pituitary hormones were: FSH 2.4\%;GH 2.0\%; and prolactin (LER-2073) $0.001 \%$. Cross-reaction of the antiserum with hCG was less than $1 \%$. The sensitivity of the assay was $0.1 \mathrm{ng}$ LH per tube. Intra-assay and interassay coefficients of variation were 8.4 and $10.5 \%$ for the serum pool $(1.77 \mathrm{ng} / \mathrm{ml} ; \mathrm{N}=10)$, respectively.

Serum oestrogen concentrations were measured by a single-antibody RIA (Lutz et al., 1984). Cross-reactions of the oestradiol- $17 \beta$ antiserum were $20 \%$ with oestrone, $2.0 \%$ with oestriol, $0.02 \%$ with dihydrotestosterone, and $<0.01 \%$ with testosterone, $\Delta^{4}$-androtenedione, $17 \beta$-hydroxyprogesterone, hydrocortisone, corticosterone, cortisone, pregnenolone, or cholesterol. Sensitivity of the oestrogen assay was $4 \mathrm{pg} / \mathrm{ml}$. Intra-asay and interassay coefficients of variation were 7.9 and $15.6 \%$ for a high serum pool ( $43 \pm 1 \mathrm{pg} / \mathrm{ml} ; \mathrm{N}=15)$ and 15.4 and $30.9 \%$ for a low serum pool $(10 \pm 1 \mathrm{pg} / \mathrm{ml} ; \mathrm{N}=15)$, respectively.

Statistical analysis. In Exp. 1, hormone data were standardized to the preovulatory LH surge (Westfahl \& Kling, 1982) in mature intact gilts and to the hCG and vehicle injection in prepubertal and ovariectomized gilts, respectively, and subjected to the general linear model split-plot in time analysis of variance procedure of the Statistical Analysis System (SAS, 1982). The $95 \%$ confidence interval was used to determine differences between treatment means (Steel \& Torrie, 1960). A hormone surge was defined as two or more successive values $50 \%$ greater than a previous nadir concentration.

In Exp. 2, the 95\% confidence interval was used to detect elevations in serum prolactin concentrations within each pig (Steel \& Torrie, 1960). At least 2 serum prolactin values obtained within $12 \mathrm{~h}$ that were significantly greater than the $95 \%$ confidence limits constituted a prolactin surge. The number of pregnant and non-pregnant gilts with and without prolactin surges were subjected to $\chi^{2}$ analysis using exact probabilities (Steel \& Torrie, 1960).

\section{Results}

\section{Experiment 1}

One prepubertal gilt was pregnant on Day 30 and 2 prepubertal gilts failed to ovulate in response to gonadotrophin treatment. These 3 gilts were therefore excluded from the statistical analysis. The serum hormone profiles of the prepubertal gilt that maintained pregnancy were similar to those of the prepubertal gilts with a preovulatory $\mathrm{LH}$ surge. The hormone concentrations of the 2 prepubertal gilts that failed to ovulate remained at basal levels throughout the sampling period. Of 5 mature intact gilts, 4 were pregnant on Day 30.

Serum $L H$. A preovulatory serum $\mathrm{LH}$ surge $(4.8 \pm 0.4 \mathrm{ng} / \mathrm{ml} ; \mathrm{N}=5)$ occurred in all mature intact gilts (Fig. la). Of the 7 prepubertal gilts that ovulated but failed to maintain pregnancy, 3 displayed a preovulatory LH surge $(13.8 \pm 3.0 \mathrm{ng} / \mathrm{ml})$ after hCG (Fig. 1b) which was of similar duration but of greater magnitude $(P<0.05)$ than the preovulatory LH surge in mature gilts. The maximum concentration of the preovulatory LH surge in these 3 gilts occurred between 12 and $24 \mathrm{~h}$ after the hCG injection.

Serum oestrogen. A preovulatory serum oestrogen surge occurred in all prepubertal and mature intact gilts. The oestrogen surge in mature intact gilts (Fig. la) began about $72 \mathrm{~h}$ before the preovulatory $\mathrm{LH}$ surge, reached a mean maximum concentrations of $42 \cdot 0 \pm 5 \cdot 4 \mathrm{pg} / \mathrm{ml}(\mathrm{N}=5)$ and lasted for 3 days. The magnitude and duration of the surge in prepubertal gilts exhibiting a preovulatory LH surge (Fig. 1b) were similar $(P>0.05)$ to those in mature gilts. The oestrogen surge was delayed by $24 \mathrm{~h}$ in prepubertal gilts $(P<0.01)$ when the data were standardized to the preovulatory LH surge in the mature intact gilts and to the hCG injection in the prepubertal gilts. However, when the data were standardized to the preovulatory LH surge in the prepubertal and mature intact gilts, the time of the oestrogen surge was similar for prepubertal and mature intact gilts. In the 


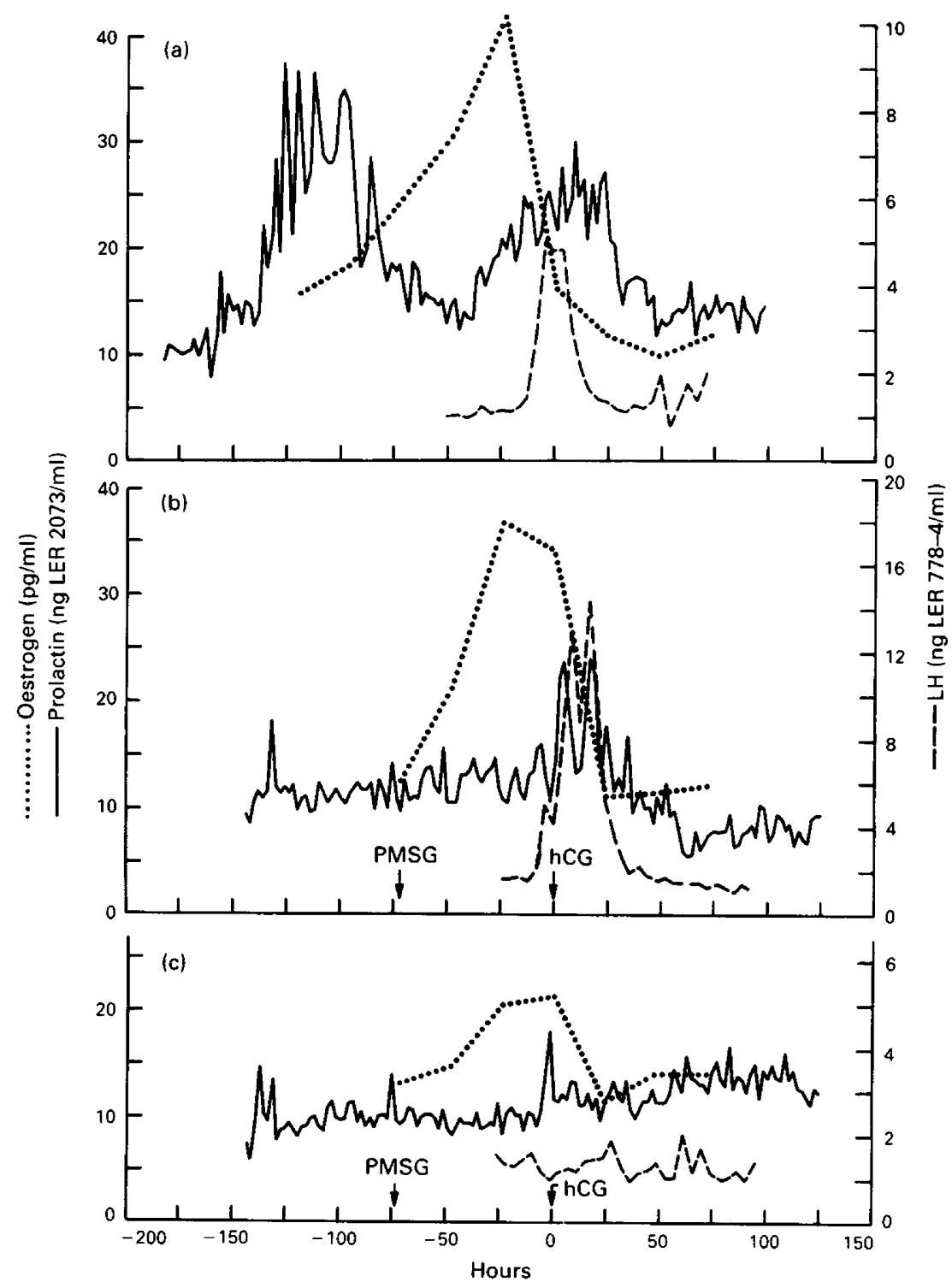

Fig. 1. Mean serum oestrogen (. . .), prolactin (-), and LH (-) concentrations in (a) 5 mature gilts during the perioestrous period, and $(b, c)$ prepubertal gilts induced to ovulate with PMSG and hCG and (b) with an LH surge present $(\mathrm{N}=3)$ or $(c)$ no $\mathrm{LH}$ surge $(\mathrm{N}=4)$. Data are standardized to the time of the LH surge ( $\mathrm{LH}$ surge $=$ Hour 0$)$ in mature gilts and to the time of the hCG injection (time of hCG = Hour 0 ) in prepubertal gilts. All gilts displayed behavioural oestrus. Blood was collected at $2 \cdot \mathrm{h}$ intervals for RIA of prolactin. LH was determined at 4-h intervals and oestrogens every $24 \mathrm{~h}$.

prepubertal gilts without a preovulatory LH surge, the oestrogen surge peaked at about the same time as in the prepubertal gilts with a preovulatory LH surge but was of lower magnitude $(P<0.01)$ and of shorter duration $(P<0.05)$ than in mature gilts and of a lower magnitude $(P<0.01)$ than in prepubertal gilts with a preovulatory LH surge (Fig. 1). 


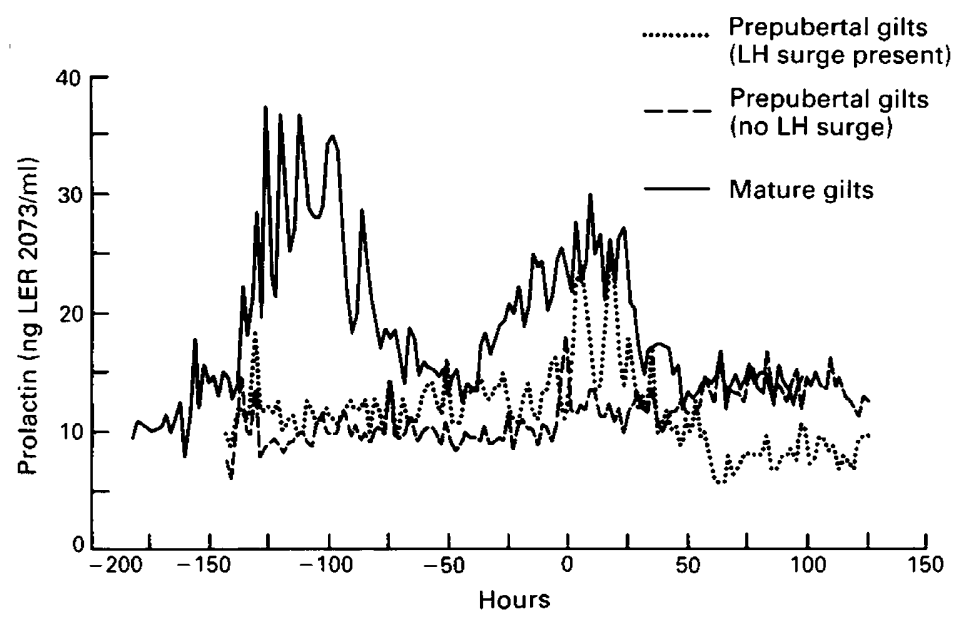

Fig. 2. Mean serum prolactin concentrations in 5 mature gilts, 4 prepubertal gilts in which no LH or prolactin surges were present and 3 prepubertal gilts in which single preovulatory LH and prolactin surges were evident. Data are standardized to the time of the hCG injection in the prepubertal gilts and to the $\mathrm{LH}$ surge in the mature gilts. Blood was collected at 2-h intervals for prolactin assay, every $4 \mathrm{~h}$ for $\mathrm{LH}$ and every $24 \mathrm{~h}$ for oestrogens.

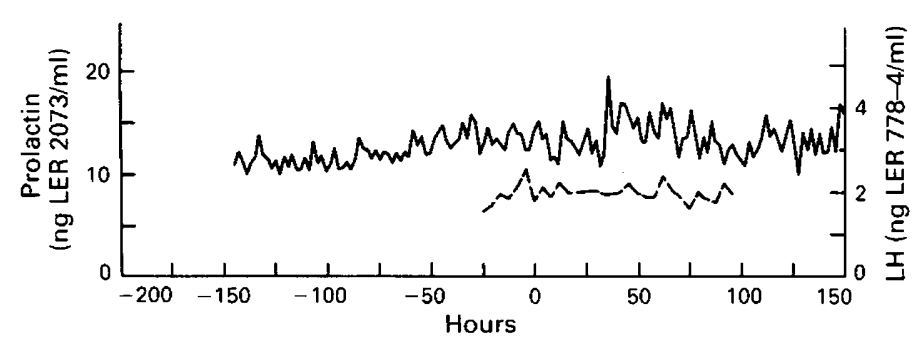

Fig. 3. Mean serum prolactin (-_--) and LH (--) concentrations in 5 mature gilts ovariectomized 14 days before the start of blood sampling. Hour $0=$ time of saline injection corresponding to the hCG injection given to prepubertal gilts. Blood for prolactin assay was collected every $2 \mathrm{~h}$ and for LH every $4 \mathrm{~h}$.

Serum prolactin. Two serum prolactin surges were present in all 5 mature intact gilts (Fig. 2). The first surge coincided with the end of the luteal phase, remained elevated for 3 days and reached a maximum concentration of $37 \cdot 2 \pm 9 \mathrm{ng} / \mathrm{ml}(\mathrm{N}=5)$. The second prolactin surge, after a 2-day nadir, began about 1 day before the preovulatory LH surge, remained elevated for 3 days and reached a maximum concentration of $27 \cdot 4 \pm 3 \cdot 2 \mathrm{ng} / \mathrm{ml}(\mathrm{N}=5)$. There were no marked increases in serum prolactin concentrations in any of the prepubertal gilts at a time comparable to the first prolactin surge in mature gilts (Fig. 2). Over the sampling interval, serum prolactin concentrations were greater $(P<0.05)$ in prepubertal gilts with an LH surge compared to prepubertal gilts without an LH surge. There were no changes $(P>0.05)$ in serum prolactin concentrations over the entire sampling period for prepubertal gilts without a preovulatory LH surge (Fig. 1c) or in the ovariectomized gilts (Fig. 3 ). In the 3 prepubertal gilts with a preovulatory LH surge, one perioestrous prolactin surge concomitant with the $\mathrm{LH}$ surge was present (Fig. $\mathrm{lb}$ ). This surge reached a maximum concentration of $24 \cdot 1 \pm 5 \cdot 3 \mathrm{ng} / \mathrm{ml}(\mathrm{N}=3)$ and remained elevated for $12 \mathrm{~h}$. 
Table 1. Serum prolactin surges in mature gilts

\begin{tabular}{lccc}
\hline Gilts & $\begin{array}{c}\text { Post-luteal } \\
\text { surge } \dagger\end{array}$ & $\begin{array}{c}\text { Periovulatory } \\
\text { surge }\end{array}$ & $\begin{array}{c}\text { Both } \\
\text { surges }\end{array}$ \\
\hline Pregnant & $4 / 5$ & $4 / 5^{*}$ & $3 / 5$ \\
Non-pregnant & $4 / 4$ & $1 / 4$ & $1 / 5$ \\
\hline
\end{tabular}

${ }^{*} P<0.04$ compared with non-pregnant gilts.

$\dagger$ This occurred between Day -6 and -3 and was evident on Days -5 and -4 in all gilts exhibiting this initial surge.

$\ddagger$ This occurred between Days -1 and +2 with the exception of 1 non-pregnant gilt for which values were elevated from Days -3 to -1 .

\section{Experiment 2}

One gilt exhibited oestrus early and was excluded due to an insufficient number of blood samples for analysis. Three of the 5 gilts which maintained pregnancy had an initial serum prolactin surge 4-5 days before the onset of oestrus and a second prolactin surge from Day 0 to Day 1 . The 2 remaining gilts that maintained pregnancy exhibited either the first or the second surge but not both (Table 1).

All gilts not maintaining pregnancy exhibited a serum prolactin surge 4-5 days before the onset of oestrus but none exhibited a periovulatory rise in serum prolactin concentration. One nonpregnant gilt had a second rise in serum prolactin concentration that occurred 2 days before the onset of oestrus. There was no difference $(P>0.05)$ between pregnant and non-pregnant gilts in the occurrence of the first prolactin surge at the end of the luteal phase. However, fewer $(P<0.04)$ of the non-pregnant pigs displayed the periovulatory prolactin surge (Table 1).

\section{Discussion}

Serum oestrogen and $\mathrm{LH}$ concentrations in mature intact gilts were similar to those described in previous reports (Brinkley, 1981; Van de Wiel et al., 1981; Barb et al., 1982; Guthrie et al., 1982). The perioestrous serum prolactin surges observed in the mature intact gilts in the present study were also comparable to reports from other laboratories (Dusza \& Krzymowska, 1979; Brinkley, 1981; Van de Wiel et al., 1981). The absence of prolactin surges in ovariectomized gilts suggests that the serum prolactin surges in prepubertal and mature intact gilts were not due to environmental influences. Van de Wiel et al. (1981) reported a diurnal variation in serum prolactin concentrations in mature intact gilts but such a variation was not detected in any of the gilts in this study.

Basal serum prolactin and LH concentrations in the prepubertal gilts without a preovulatory $\mathrm{LH}$ surge were similar to those in mature intact gilts and the prepubertal gilts with a preovulatory LH surge. However, in the prepubertal gilts lacking a preovulatory LH surge there were no perioestrous prolactin surges and the oestrogen surge was of a lesser magnitude and duration than in mature intact gilts or prepubertal gilts with a preovulatory LH surge. This is consistent with the concept that a threshold serum oestrogen concentration must be attained to cause a positive feedback on gonadotrophin secretion (Van de Wiel et al., 1981), as was further illustrated by the increased perioestrous serum oestrogen concentrations in prepubertal gilts with $\mathrm{LH}$ and prolactin surges. In contrast to a report in which 180-day-old gilts were induced to ovulate with a single injection of PMSG only (Rampacek et al., 1976), prepubertal gilts with a preovulatory LH surge in the present study exhibited an LH surge of shorter duration (1 day compared to 2 days), that began when oestrogen was elevated, rather than after oestrogen declined. Additionally, all prepubertal gilts that ovulated displayed behavioural oestrus. This contradicts the suggestion by Van de Wiel et al. (1981) that perioestrous prolactin surges may be required for oestrous activity. 
Because 2 perioestrous prolactin surges were present in all 5 mature gilts in Exp. 1, serum prolactin concentrations were measured during the perioestrous period in a second group of mature gilts, to determine whether both surges were obligatory to pregnancy maintenance. The sampling interval chosen in Exp. 2 was sufficient to detect the presence of prolactin surges but not to characterize surges as in Exp. 1. Of 5 gilts that maintained pregnancy $3 \mathrm{had} 2$ perioestrous prolactin surges but the other 2 gilts exhibited either the first or the second prolactin surge but not both. In contrast, all gilts not maintaining pregnancy exhibited an initial prolactin surge 4-5 days before the onset of oestrus but only 1 gilt exhibited a preovulatory prolactin surge that began 2 days before oestrus. While pregnant gilts displayed a second serum prolactin surge more often than non-pregnant gilts, 2 distinct serum prolactin surges were not mandatory for pregnancy maintenance.

The apparent differences in the temporal relationships amongst serum prolactin, oestrogen and LH concentrations during the perioestrous period in prepubertal gilts induced to ovulate and mature gilts may adversely affect the biological activity of these hormones in the prepubertal animal. These differences could sufficiently hinder embryo or corpus luteum development, leading to failure of pregnancy maintenance.

This work was supported by State and Hatch funds allocated to the Georgia Agr. Exp. Stn and by USDA funds. We thank Dr T. E. Kiser, Dr F. N. Thompson, Dr R. D. Page and Dr B. N. Day for assistance and critical evaluation of this project; D. Powell, B. Johnson, M. Hart and the graduate students in the co-operative reproduction program; D. E. Little and R. A. Wilson for help with statistical analysis; M. L. Lewis for secretarial assistance; and Dr L. E. Reichert and Dr D. J. Bolt for supplies of purified pituitary hormones used in the radioimmunoassays.

\section{References}

Advis, J.P., White, S.S. \& Ojeda, S.R. (1981) Delayed puberty induced by chronic suppression of prolactin release in the female rat. Endocrinology 109, 1321-1330.

Alvarez, E.O., Hancke, J.L. \& Advis, J.P. (1977) Indirect evidences of prolactin involvement in precocious puberty induced by hypothalamic lesions in female rats. Acta endocr., Copenh. 85, 11-18.

Barb, C.R., Kraeling, R.R., Rampacek, G.B., Fonda, E.S. \& Kiser, T.E. (1982) Inhibition of ovulation and LH secretion in the gilt after treatment with ACTH or hydrocortisone. J. Reprod. Fert. 64, 85-92.

Bevers, M.M., Willemse, A.H. \& Kruip, T.A.M. (1978) Plasma prolactin levels in the sow during lactation and the postweaning period as measured by radioimmunoassay. Biol. Reprod. 19, 628-634.

Brinkley, H.J. (1981) Endocrine signaling and female reproduction. Biol. Reprod. 24, 22-43.

Dusza, L. \& Krzymowska, H. (1979) Plasma prolactin concentrations during the oestrous cycle of sows. $J$. Reprod. Fert. 57, 511-514.

Esbenshade, K.L., Paterson, A.M., Cantley, T.C. \& Day, B.N. (1982) Changes in plasma hormone concentrations associated with the onset of puberty in the gilt. J. Anim. Sci. 54, 320-324.

Fonda, E.S., Diehl, J.R., Barb, C.R., Kiser, T.E., Kraeling, R.R. \& Rampacek, G.B. (1981) Serum luteinizing hormone, testosterone, prolactin and cortisol concentrations after $\mathrm{PGF}_{2 a}$ in the boar. Prostaglandins 21, 933-943.

Foxcroft, G.R. \& Van de Wiel, D.F.M. (1982) Endocrine control of the oestrous cycle. In Control of Pig
Reproduction, pp. 161-177. Eds D. J. A. Cole \& G. R. Foxcroft. Butterworths, London.

Guthrie, H.D., Henricks, D.M. \& Handlin, D.L. (1982) Plasma estrogen, progesterone and luteinizing hormone prior to estrus and during early pregnancy in pigs. Endocrinology 91, 675-679.

Henricks, D.M., Guthrie, H.D. \& Handlin, D.L. (1972) Plasma estrogen, progesterone and luteinizing hormone levels during the estrous cycle in pigs. Biol. Reprod. 6, 210-218.

Kraeling, R.R., Barb, C.R. \& Davis, B.T. (1975) Prostaglandin induced regression of porcine corpora lutea maintained by estrogen. Prostaglandins 9, 459-462.

Kraeling, R.R., Rampacek, G.B., Cox, N.M. \& Kiser, T.E. (1982a) Prolactin and luteinizing hormone secretion after bromocryptine (CB-154) treatment in lactating sows and ovariectomized gilts. J. Anim. Sci. 54, $1212-1220$.

Kraeling, R.R., Rampacek, G.B. \& Kiser, T.E. (1982b) Alteration of the estrous cycle of gilts by movement to a confinement housing system. Theriogenology 17, 453-457.

Lutz, J.B., Rampacek, G.B., Kraeling, R.R. \& Pinkert, C.A. (1984) Serum luteinizing hormone and estrogen profiles before puberty in the gilt. J. Anim. Sci. 58, 686-691.

Paterson, A.M. (1982) The controlled induction of puberty. In Control of Pig Reproduction, pp. 139-159. Eds D. J. A. Cole \& G. R. Foxcroft. Butterworths, London.

Paterson, A.M. \& Martin, G.B. (1981) Induction of puberty in gilts. Anim. Prod. 32, 55-59. 
Puglisi, T.A., Rampacek, G.B. \& Kraeling, R.R. (1978) Corpus luteum function following subtotal hysterectomy in the prepuberal gilt. J. Anim. Sci.46,707-710.

Puglisi, T.A., Rampacek, G.B., Kraeling, R.R. \& Kiser, T.E. (1979) Corpus luteum susceptibility to prostaglandin $\mathrm{F}_{2 a}\left(\mathrm{PGF}_{2 a}\right)$ luteolysis in hysterectomized prepuberal and mature gilts. Prostaglandins 18, 257-264.

Rampacek, G.B. \& Kraeling, R.R. (1978) Effect of estrogen on luteal function in prepuberal gilts. J. Anim. Sci.46, 453-457.

Rampacek, G.B., Kraeling, R.R. \& Ball, G.D. (1976) Luteal function in the hysterectomized prepuberal gilt. J. Anim. Sci. 43, 792-794.

Rampacek, G.B., Schwartz, F.L., Fellows, R.E., Robison, O.W. \& Ulberg, L.C. (1976) Initiation of reproductive function and subsequent activity of the corpora lutea in prepuberal gilts. J. Anim. Sci. 42, 881-887.

Rampacek, G.B., Kraeling, R.R. \& Pinkert, C.A. (1985) Regression of induced corpora lutea by human chorionic gonadotropin in prepuberal gilts. J. Anim. Sci. 60, 1040-1044.

SAS (1982) SAS User's Guide. Statistical Analysis System Institute, Cary, NC.
Steel, R.D.G. \& Torrie, J.H. (1960) Principles and Procedures of Statistics. McGraw-Hill Book Co. Inc, New York.

Van de Wiel, D.F.M., Erkens, J., Koops, W., Vos, E. \& Van Landeghem, A.A.J. (1981) Periestrous and midluteal time courses of circulating LH, FSH, prolactin, estradiol-17 $\beta$ and progesterone in the domestic pig. Biol. Reprod. 24, 223-233.

Van Landeghem, A.A.J. \& Van de Wiel, D.F.M. (1978) Radioimmunoassay for porcine prolactin: plasma levels during lactation, suckling and weaning and after TRH administration. Acta endocr., Copenh. 88, 653-667.

Westfahl, P.K. \& Kling, O.R. (1982) Relationship of estradiol to luteal function in the cycling baboon. Endocrinology 110, 64-69.

Wuttke, W., Dohler, K.D. \& Gelato, M. (1976) Oestrogens and prolactin as possible regulators of puberty. $J$. Endocr. 68, 391-396.

Received 12 October 1987 